\title{
Response preference and choice-sequence preferences: I. Regression to alternation'
}

\author{
IRMA R. GERJUOY AND JOHN J. WINTERS, JR. \\ EDWARD R. JOHNSTONE TRAINING AND RESEARCH CENTER, BORDENTOWN, N. J.
}

Five numerical binary-choice tasks, of varying difficulty, were administered to normal fourth- through eighth-grade children and adolescent educable retardates. Retardates atternated more than normals in all tasks. Alternation was greatest for the most difficult task. This nonadaptive behavior that is lower in the developmental hierarchy may be called "regression to alternation."

Normal children and adolescent educable retardates tend to use alternation as their primary strategy in a wide variety of tasks from binary-choice guessing games to binary-choice learning tasks. Regardless of the reinforcement schedule these populations utilize alternation more than any other response sequence. When retardates do try some other strategy and receive nonreinforcement, they will switch to alternation even if it does not improve their percentage of reinforcements.

In order to test the hypothesis that retardates and normal children choose this lower form of behavior in an objectively soluble binary-choice task that is too difficult for them to solve, first- through fifth-grade normal children and adolescent educable retardates were administered a spatial orientation task(Gerjuoy, Winters, \& Hoats, 1966) in which they were required to respond "left" or "right" at each choice point of the Road Map Test (Money, 1965). Only the fourth-and fifth-graders and the retardates had significantly fewer errors than chance. All groups alternated significantly above chance with retardates producing the most alternations. The younger normals tended to alternate more than the older normals.

If a soluble task has several levels of difficulty, we can assume from these results that as the task becomes more difficult, more Ss would exhibit alternation, and if it then becomes easier, fewer Ss would alternate above chance. In order to test this hypothesis, the present experiment was designed to include tasks with several levels of difficulty.

\section{Subjects and Procedure}

Ss were 28 adolescent educable retardates $(\overline{\mathrm{CA}}=15.8$ years, $\sigma=1.5$ years; $\overline{\mathrm{IQ}}=63, \sigma=9.7$ ) and 263 fourththrough eighth-grade normal children.

Ss were presented five numerical binary-choice tasks with the same format. Each task had a number centered at the top followed by pairs of two- or three-digit numbers. Task 2, for example, was headed by the number "70." Each pair of two-digit numbers included one with a zero in the units column. Tasks $1,2,4$, and 5 had 10 trials, whereas Task 3 included 20 trials. The 10-trial tasks were presented consecutively, two to a page; the 20-trial task was presented separately after the first pair of tasks. Each task was judged for level of difficulty; the first and last tasks were judged easiest, the second and fourth more difficult, and the third most difficult. Ss, who were tested in their classrooms, were instructed to circle the number in each pair that was more similar to the top number. Examples with easier tasks were placed on the blackboard, and $\mathrm{E}$ worked through the examples with each class to assure the instructions were understood. Ss then proceeded at their own pace until the five tasks were completed.

Results

Ss who followed any consistent pattern, such as always circling the larger number or the smaller number, or circling the number that Es considered the correct solution, were considered to have solved that problem. The data from those Ss with no solution to a problem were analyzed. Since the data from the fourth-through eighthgrade children did not differ reliably, they were combined and compared with those of the retardates.

It was found that the number of Ss in both populations whose left-hand responses were above the median was significantly greater than the number of Ss whose left responses were below the median $\left(\mathrm{X}^{2}=18.94, \mathrm{p}<.001\right.$ for normals; $X^{2}=7.11, p<.01$ for retardates). In other words, when Ss found no solution they tended to circle the left-hand number more frequently than the righthand number.

The percentages of Ss from each population with no acceptable solution for each task are presented in Table 1.

Inspection of Table 1 reveals that Task 3 was, in fact, the most difficult while the others were less difficult in the predicted order. Fewer retardates found solutions for any of the tasks than did the normals. Collapsing over the five tasks, alternation was found to be significantly above chance for each population $\left(X^{2}=6.68, p<\right.$ .01 , normals; $\mathrm{X}^{2}=37.35, \mathrm{p}<.001$, retardates). Retardates, however, alternated significantly more than normal children $\left(x^{2}=14.13, p<.001\right)$. In addition, some retardates displayed invariant alternation, i.e., they alternated throughout the task, a strategy that was not used by normals. The gradient of difficulty of the task was also related to the amount of alternation. Normals alternated significantly more on Task 3 than on the other

Table 1. Percentages of Ss with No Acceptable Solution on Each of the Five Tasks

\begin{tabular}{lccccc} 
Population & Task 1 & Task 2 & Task 3 & Task 4 & Task 5 \\
\hline Normals & 4 & 16 & 28 & 11 & 3 \\
Retordates & 54 & 71 & 71 & 57 & 39 \\
\hline
\end{tabular}


tasks $\left(X^{2}=25.23, p<.001\right)$; their above chance alternation was contributed almost entirely by Task 3 . The difference in amounts of alternation between Task 3 and the other tasks almost reached significance $\left(\mathrm{X}^{2}=3.50\right.$, $\mathrm{p}<.10)$ for the retardates whose overall alternation was extremely high.

\section{Discussion}

Response Preferences and Choice-Sequence Preferences. In this study only the data of those Ss who failed to find a solution to a task has been analyzed. Since equal numbers of left and right responses and perseverations and alternations were built into the correct solutions for the tasks, the data from solvers would not contribute to a further understanding of response preferences and choice-sequence preferences. These Ss were able to find a task-oriented consistent strategy.

Both normal and retarded non-solvers had an overall preference to respond to the left-hand stimulus. This preference in a paper-and-pencil task with numerical material is to the same side as, but larger than, that found with alphabetic material (Gerjuoy \& Gerjuoy, 1965). This is in contrast to the right-side preference found with unfamiliar Japanese symbols (Gerjuoy \& Winters, 1965). It is possible that the type of material may determine the side of a response preference in this type of task.

Since response preferences and alternation preferences are antagonistic strategies-i.e., an invariant preference to respond to one side would produce perseveration, and eliminate alternation, whereas invariant alternation would eliminate a response preference-an increase in either of these tendencies would decrease the other. This is seen in the comparison of Tasks 1, 2,4 , and 5 with Task 3 for the normals. For the former tasks the number of left responses are significantly greater than for the latter task. On the other hand, normal Ss alternated more on Task 3 than on the other tasks. For retardates, however, no significant differences between tasks were found for either a side preference or an alternation preference, although what changes occurred were in the samedirection as with the normals.

In order to determine whether the greater difficulty of Task 3 might be related to its length and a change of strategy over trials, the number of alternations over the first 10 trials was compared with the number of alternations over the last 10 trials for each population. Neither of these comparisons yielded a significant difference. It would appear that the problem itself, rather than the length of the task, led to the strong alternation behavior.

Response Hierarchy and Regression to Altemation. In a review of the development of response strategies in children and retardates (Gerjuoy \& Winters, in press) an orderly developmental hierarchy was found. The earliest response sequence is invariant perseveration, followed by invariant alternation, then alternation above chance, and finally either more random responding or longer, more complicated patterns. This hierarchy occurs not only in tasks without feedback butalso under a wide variety of reinforcement schedules. We would expect that most of the normal children of the ages in this study (approximately 9 to 14 years) would alternate somewhat above chance, although some might already have reached a higher response level. In this study, normal non-solvers did not alternate above chance except in Task 3. Adolescent educable retardates have been found to alternate above chance, sometimes invariantly, in a number of studies. In the present study, retardates alternated above chance in all tasks, but even more so in Task 3. Some retardates alternated invariantly, which raised the overall percentage of alternation for the retarded group.

Tasks $1,2,4$, and 5 may be considered the base level of alternation for this type of task. A more difficult problem, such as Task 3, tends to elicit a lower level of behavior, or Ss may be said to regress to alternation with a more difficult task.

This is more true of the normals than the retardates, in comparing the five tasks. It can be seen from Table 1 , however, that the retardates found all the tasks difficult and regression to alternation might apply to their behavior in all five tasks. As the task became more difficult alternation increased among the normal nonsolvers; as it became easier again, alternation decreased. Perhaps amount of alternation could be used as an index of task difficulty for these populations.

\section{References}

Gerjuoy, I. R., \& Gerjuoy, H. Binary-choice sequences of retardates, normal children, and college students under random- and pattern-set instructions. Amer. J. ment. Defic., 1965, 69, 854859.

Gerjuoy, I. R., \& Winters, J. J., Jr. Binary-choice responses of retardates, normal children, and college students to similar or dissimilar stimuli. Amer. J. ment. Defic., 1965, 70, 474-477.

Gerjuoy, I. R., \& Winters, J. J., Jr. Development of lateral and choice sequence preference. In N. R. Ellis (Ed.), International review of research in mental retardation. Vol. III. New York: Academic Press, in press.

Gerjuoy, I. R., Winters, J. J., Jr., \& Hoats, D. L. Alternation in a spatial orientation task. Psychon. Sci., 1966, 5, 83-84.

Money, J. A standardized road-map test of direction sense. Baltimore, Md.: The Johns Hopkins Press, 1965.

\section{Note}

1. The authors wish to express appreciation to José M. Alvarez for data collection and to Martha $M$. Pullen for data analysis. We are grateful to Samuel Kaltovich, Principal, Florence Township, N. J., for his generosity in providing the normal children. We also wish to thank Herman H. Spitz for his critical reading of the manuscript. 